\title{
Palmelloids formation in Chlamydomonas reinhardtii : defence against rotifer predators?
}

\author{
M. Lurling*, W. Beekman
}

Aquatic Ecology \& Water Quality Management, Department of Environmental Sciences, Wageningen University, PO Box 8080, NL-6700DD Wageningen, The Netherlands.

\begin{abstract}
The green alga Chlamydomonas reinhardtii usually occurs in cultures as single, biflagellated cells. However, C. reinhardtii is known for its ability to form gelatinous and palmelloid stages that arise as a result of an interaction with its environment. Exponentially growing unicellular $C$. reinhardtii formed palmelloid colonies rapidly within $25 \mathrm{~h}$ when cultured together with their enemy the rotifer Brachionus calyciflorus. Consequences of palmelloid formation for population dynamics of both $C$. reinhardtii and B. calyciflorus were examined in continuous flow systems. Palmelloids were only formed in a one-stage system where B. calyciflorus grazers and $C$. reinhardtii prey were cultured together, but not in a two-stage system in which mainly unicellular $C$. reinhardtii was pumped into a rotifer culture placed in darkness. The rotifer abundance was lower and the algal biomass higher in the one-stage system compared to the grazing unit of the two-stage system. Inasmuch as palmelloids seemed to give $C$. reinhardtii cells resistance to grazing, we suggest that at least one of the reasons why $C$. reinhardtii is capable of forming palmelloids is to cope with herbivory.
\end{abstract}

Keywords : Activated defences, Colony formation, Inducible defences, Morphology, Plankton interactions.

\section{Introduction}

Phytoplankton species are challenged to cope with environmental heterogeneity and to survive, grow and reproduce in rather unpredictable environments. Short time-scales switching from favourable to hostile environmental conditions provide an arena for algae to alter their physiology and morphology to meet the new environmental demands. The most hostile conditions to phytoplankton are periods when numerous grazers are wandering around and grazing pressure is severe. Especially the nanoplanktonic species with dimensions between 2 and $30 \mu \mathrm{m}$ are considered highly susceptible to zooplankton grazing (Porter 1973, Sterner 1989). Larger algal species with $20-30 \mu \mathrm{m}$ or more in longest dimension may withstand grazing pressure effectively (Porter 1973). The morphological solution of

* Corresponding author :

E-mail: miquel.lurling@wur.nl becoming too large to be consumed is, however, opposed by the selection pressure of resource acquisition favouring smaller sizes (Lehman 1988). Because grazing pressure fluctuates both on spatial and temporal scale, the conflicting set of natural challenges will favour the evolution of plastic genotypes enabling algae to track environmental changes and respond appropriately (Morales et al. 2002).

Morphological variability seems widespread among phytoplankton and has been described in chlorophytes, cyanobacteria, diatoms and dinoflagellates (Hutchinson 1967, Trainor et al. 1971, Van Donk 1997), but research on causal factors mainly has been focussed on the physico-chemical environment (Trainor 1998). Nevertheless, some studies suggested that the presence of grazers could alter the morphology of phytoplankton. The filamentous cyanobacterium Aphanizomenon appeared as flakes in the presence of the grazer Daphnia, but as single filaments in their absence (Lynch 1980, Holm et al. 1983). Mikheeva \& Kruchkova (1980) described that members of the chlorophyte genera Scene- 
desmus and Chlamydomonas formed colonies in the presence of herbivorous zooplankton. Divisive colony formation in Scenedesmus has been studied intensively the last decade and has become a paradigm of induced defences in phytoplankton (Hessen \& Van Donk 1993, Lampert et al. 1994, Lürling 1998, von Elert \& Franck 1999, van Holthoon et al. 2003). In contrast, until now no studies have been undertaken to verify the second part of the findings of Mikheeva \& Kruchkova (1980) and to examine the potential of grazer-induced phenotypic plasticity in Chlamydomonas. The first objective of the current study was to test the hypothesis that zooplankton (the rotifer Brachionus calyciflorus) can induce palmelloid formation in Chlamydomonas as has been found for Scenedesmus (Lürling \& Van Donk 1997).

Forming colonies made Scenedesmus more difficult to eat by zooplankton and reduced the enemy's population growth (Hessen \& Van Donk 1993, Lürling \& Van Donk 1996). In those studies, defended algae were fed at a constant concentration to the consumers and their effects on zooplankton were examined. However, to improve our understanding of the dynamics of induced defences, an assessment of the population consequences for both grazer and algal prey is required (Tollrian \& Harvell 1999). Simulations with a predator-prey model for algae and rotifers (Brachionus) predicted that induced defences in algae stabilised the population dynamics of this system; increased algal biomass and decreased rotifer biomass (Vos et al. 2004). The second objective of the current study was to test these modelling predictions experimentally for continuous flow systems with $C$. reinhardtii as prey and $B$. calyciflorus as predators. Formation of palmelloid colonies in $C$. reinhardtii is expected to occur in a onestage system where $B$. calyciflorus grazers and $C$. reinhardtii prey are cultured together, but not in a two-stage system in which unicellular $C$. reinhardtii is pumped into a rotifer culture placed in darkness. Inasmuch as palmelloids are expected to give $C$. reinhardtii resistance to grazing, the rotifer abundance is expected to be lower and the algal biomass to be higher in the one-stage system compared to the two-stage system.

\section{Materials and methods}

\section{Organisms}

The green alga Chlamydomonas reinhardtii Dangeard (strain NIVA-CHL13) originated from the Norwegian Institute for Water Research (NIVA, Norway). Chlamydomonas stock cultures were maintained in
$300 \mathrm{ml}$ Erlenmeyer flasks containing $150 \mathrm{ml}$ of a modified WC-medium (Table 1) and were transferred every three weeks into fresh sterile medium. The flasks were placed in a climate-controlled room at $20^{\circ} \mathrm{C}$ and in continuous light of $60 \mu \mathrm{mol}$ quanta $\mathrm{m}^{-2} \mathrm{~s}^{-1}$ (PAR) provided from above by fluorescent cool-white tubes (Osram L 36W/21-840).

The rotifer Brachionus calyciflorus Pallas was obtained from Microbiotests Inc. (Nazareth, Belgium) and was supplied as cysts. Prior to the experiments, cysts were transferred to $100 \mathrm{ml}$ Erlenmeyer flasks containing $50 \mathrm{ml}$ of an unicellular Chlamydomonas suspension (at $10 \mathrm{mg} \mathrm{C}^{-1}$ ). The flasks were placed on a rotating shaking device $\left(60 \mathrm{rpm}\right.$.) at $24^{\circ} \mathrm{C}$ in continuous light of $100 \mu \mathrm{mol}$ quanta $\mathrm{m}^{-2} \mathrm{~s}^{-1}$ and experimental animals were collected after 2-3 days.

\section{Short-term assay}

To examine whether palmelloid colony formation in Chlamydomonas reinhardtii can be induced by the rotifer Brachionus calyciflorus, animals were added to unicellular $C$. reinhardtii populations. Unicellular $C$. reinhardtii populations were obtained by transferring an inoculum from the stock culture to $50 \mathrm{ml}$ sterile medium in an cellulose-plug stopped $100 \mathrm{ml}$ Erlenmeyer flask making an initial concentration of $5 \times 10^{6} \mu \mathrm{m}^{3}$ $\mathrm{ml}^{-1}$. After three days on a rotating shaking device $(60$ rpm.) at $24^{\circ} \mathrm{C}$ in continuous light of $100 \mu \mathrm{mol}$ quanta

Table 1. Composition of algal growth medium (final concentrations in $\mathrm{mg}^{-1}$ ).

\begin{tabular}{|c|c|c|c|}
\hline Major nutrients & $\mathrm{mg} \mathrm{l}^{-1}$ & Trace elements & $\mathrm{mg} \mathrm{l}^{-1}$ \\
\hline $\mathrm{NaNO}_{3}$ & 85.01 & $\mathrm{Na}_{2}$ EDTA $2 \mathrm{H}_{2} \mathrm{O}$ & 4.36 \\
\hline $\mathrm{MgSO}_{4} \cdot 7 \mathrm{H}_{2} \mathrm{O}$ & 36.97 & $\mathrm{FeCl}_{3} \cdot 6 \mathrm{H}_{2} \mathrm{O}$ & 1.00 \\
\hline $\mathrm{CaCl}_{2} \cdot 2 \mathrm{H}_{2} \mathrm{O}$ & 36.76 & $\mathrm{MnCl}_{2} \cdot 4 \mathrm{H}_{2} \mathrm{O}$ & 0.18 \\
\hline $\mathrm{Na}_{2} \mathrm{SiO}_{3} \cdot 9 \mathrm{H}_{2} \mathrm{O}$ & 28.42 & $\mathrm{CuSO}_{4} \cdot 5 \mathrm{H}_{2} \mathrm{O}$ & 0.001 \\
\hline $\mathrm{H}_{3} \mathrm{BO}_{3}$ & 24.00 & $\mathrm{ZnSO}_{4} \cdot 7 \mathrm{H}_{2} \mathrm{O}$ & 0.022 \\
\hline $\mathrm{NaHCO}_{3}$ & 12.60 & $\mathrm{NaMoO}_{4} \cdot 2 \mathrm{H}_{2} \mathrm{O}$ & 0.022 \\
\hline $\mathrm{K}_{2} \mathrm{HPO}_{4}$ & 8.71 & $\mathrm{CoCl}_{2} \cdot 6 \mathrm{H}_{2} \mathrm{O}$ & 0.012 \\
\hline Vitamins & $\mathrm{mg} \mathrm{l}^{-1}$ & $\mathrm{Na}_{3} \mathrm{VO}_{4}$ & 0.0018 \\
\hline Biotin B1 & 0.00005 & $\mathrm{H}_{2} \mathrm{SeO}_{3}$ & 0.0016 \\
\hline B12 & 0.00005 & Buffer & $\mathrm{mg} \mathrm{l}^{-1}$ \\
\hline Thiamine $\mathrm{HCl}$ & 0.0001 & $\mathrm{TES}^{\mathrm{a}}$ & 85.00 \\
\hline
\end{tabular}

a TES $=N$-Tris(hydroxymethyl)-methyl-2-aminoethane-sulphonic acid $\left(\mathrm{C}_{6} \mathrm{H}_{15} \mathrm{NO}_{6} \mathrm{~S}\right)$; Sigma T-1375 
$\mathrm{m}^{-2} \mathrm{~s}^{-1}$ again $C$. reinhardtii was transferred to $50 \mathrm{ml}$ sterile medium. Exponentially growing algae from this culture were used in the experiment.

Prior to the experiment, B. calyciflorus were hatched and 25 animals were transferred to each of three replicate $100 \mathrm{ml}$ Erlenmeyer flasks containing $50 \mathrm{ml}$ of sterile medium (treatments), while three other flasks contained no animals but only $50 \mathrm{ml} \mathrm{WC}$-medium (controls). C. reinhardtii was added to each flask at identical initial concentrations of $5 \times 10^{6} \mu \mathrm{m}^{3} \mathrm{ml}^{-1}$ (i.e. $2.2 \times 10^{4}$ cells $\left.\mathrm{ml}^{-1}\right)$. These flasks were placed for $25 \mathrm{~h}$ on a rotating shaking table $(60 \mathrm{rpm}$.) in a climate controlled chamber at $24^{\circ} \mathrm{C}$ and continuously illuminated from above by cool-fluorescent white tubes at $100 \mu \mathrm{mol}$ quanta $\mathrm{m}^{-2} \mathrm{~s}^{-1}$. Algal size distributions and densities were measured in the range of $3-30 \mu \mathrm{m}$ ESD (equivalent spherical diameter) using a Coulter ${ }^{\circledR}$ Multisizer II particle counter (capillary $100 \mu \mathrm{m}$ orifice width, Coulter Electronics Limited, Luton, England). Volume-based algal growth rates were calculated from increase in algal biovolumes (V) according to $\mu=$ $\left\{\ln \left(V_{t}\right)-\ln \left(V_{0}\right)\right\} \times \Delta t^{-1}$, with $\Delta t=$ incubation time (in d), $V_{t}=$ algal volume after $25 \mathrm{~h}$ and $V_{0}=$ initial algal biovolume. An estimation of rotifer clearance rates $\left(\mathrm{CR}, \mu 1\right.$ rotifer-1 $^{-1} \mathrm{~h}^{-1}$ ) was obtained using the equation of Peters (1984) :

$$
\begin{gathered}
\mathrm{CR}=(b-a) \times \frac{V}{N} \\
\text { with } b=\left(\frac{\left(\ln \left(A_{C, t=1}\right)-\ln \left(A_{C, t=0}\right)\right)}{\Delta t}\right) \text { and } a=\left(\frac{\left(\ln \left(A_{T, t=1}\right)-\ln \left(A_{T, t=0}\right)\right)}{\Delta t}\right) \text {, where } A_{C, t=0}
\end{gathered}
$$

is the final algal concentration (biovolume in $\mu \mathrm{m}^{3}$ $\mathrm{ml}^{-1}$ ) in controls, $\mathrm{A}_{C, t=1}$ is the final algal concentration in controls, $A_{T, t=0}$ is the initial algal concentration in the treatments $A_{T, t=1}$ is the final algal concentration in the treatments, $\Delta t$ is the time $(25 \mathrm{~h}), V$ is the culture volume $(50 \mathrm{ml})$ and $N$ is the number of animals $(=25)$.

The numbers of cells per aggregate in the different C. reinhardtii populations were determined microscopically by counting at least 100 aggregates (i.e. unicells and colonies), using a Nikon light microscope at $400 \mathrm{x}$ magnification. Comparison of the mean particle volumes, numbers of cells per colony and growth rates in controls and treatments was done by running a $t$-test preceded by Levene's equality of variances test in the statistical tool pack SPSS ${ }^{\circledR}$ version 10.1.0.

\section{Chemostat experiment}

To examine the consequences for population dynamics of both $C$. reinhardtii and B. calyciflorus and test the hypothesis that palmelloid colonies gives $C$. rein- hardtii more resistance to grazing both $C$. reinhardtii and $B$. calyciflorus were cultured in highly controlled continuous systems. Both species were cultured for 50 days in a two-stage and a one-stage predator-prey system consisting of 550-ml glass chemostats (Fig. 1). In the two-stage system, the overflow of a 550-ml chemostat, in which $C$. reinhardtii was cultured, was connected to a 550-ml vessel that was placed in darkness (Fig. 1). This latter vessel was inoculated with $B$. calyciflorus at 0.1 rotifer $\mathrm{ml}^{-1}$. In the one-stage system, both $C$. reinhardtii and $B$. calyciflorus (also started at 0.1 rotifer $\mathrm{ml}^{-1}$ ) were cultured in the same $550-\mathrm{ml}$ glass vessel. The algal growth vessel in the two-stage system and the one-stage system received a continuous flow of sterile WC-medium such that all vessels were subjected to a dilution rate of $0.50( \pm 0.02) \mathrm{d}^{-1}$. Air was bubbled to prevent carbon limitation of $C$. reinhardtii and to enhance mixing. The chemostats were maintained at $24 \pm 0.5{ }^{\circ} \mathrm{C}$ and at continuous fluorescent illumination of $90 \pm 5 \mu \mathrm{mol}$ quanta $\mathrm{m}^{-2} \mathrm{~s}^{-1}$, with exception of the rotifer vessel in the two-stage system that was placed in darkness to prevent algal growth. $B$. calyciflorus was counted under a dissecting microscope at 20 x magnification, whereas $C$. reinhardtii was counted using a Coulter ${ }^{\circledR}$ Multisizer II particle counter. The number of $C$. reinhardtii cells per aggregate was determined microscopically.

\section{Results}

\section{Short-term assay}

$C$. reinhardtii populations that had been cultured for 25 hours in presence of $B$. calyciflorus showed a significantly higher mean particle volume $(t=-4.74 ; \mathrm{df}=$ $4 ; p=0.009)$ and mean number of cells per aggregate $(t=-4.81 ; \mathrm{df}=4 ; p=0.009)$ than in their absence (controls) (Fig. 2). The composition of the populations reflects the morphological changes. Where unicells made up $65 \pm 9 \%$ of the control populations, this was only $30 \pm 12 \%$ in treatments (Fig. 2). The share of two-celled particles was similar in controls and treatments (both $5 \%$ ) ; four-celled aggregates were slightly more abundant in treatments $(17 \pm 4 \%)$ than in controls $(14 \pm 4 \%)$, and eight-celled aggregates were considerably more abundant in treatments $(22 \pm 7 \%)$ compared to control populations $(8 \pm 2 \%)$ (Fig. 2). Aggregates with more than 10 cells comprised $8 \pm 2 \%$ of treatment populations and $3 \pm 1 \%$ of controls. The rest-group (Fig. 2) included 3-, 5-, 6-, 7-, and 9-celled 


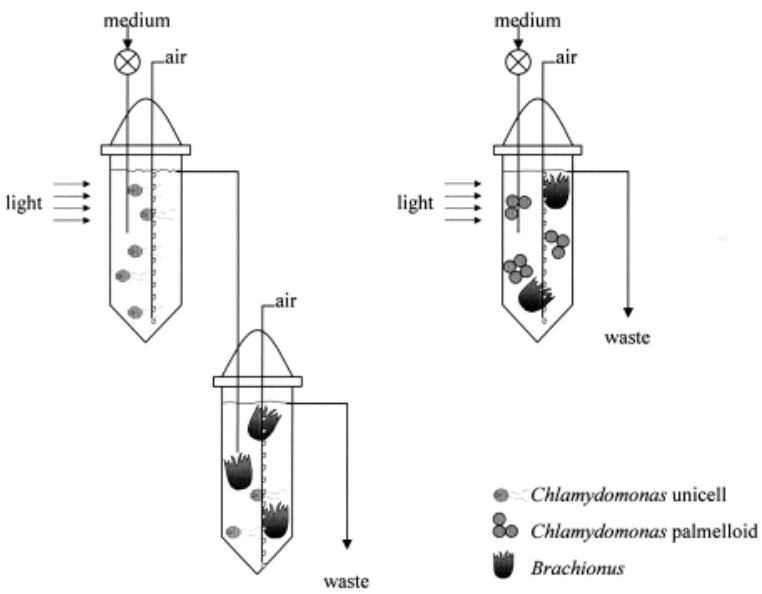

Fig. 1. Schematic representation of a simultaneously operated twostage continuous flow system (left) and one-stage system (right) with similar flow rates $\left(0.50 \pm 0.02 \mathrm{~d}^{-1}\right)$. In the two-stage system, the first reactor is used for growth of the alga Chlamydomonas reinhardtii, which is pumped into a second reactor, placed in darkness, with the rotifer Brachionus calyciflorus. In the one stage system both algae and rotifers are cultured together.

aggregates and made up $5 \pm 1 \%$ of controls, but $18 \pm$ $2 \%$ of treatment populations. Digital images (Leica Quantimet 500 MC coupled to a Nikon light microscope at $600 \mathrm{x}$ magnification) of unicells from control populations and aggregates from treatments are given in figure 3 .

Growth of $C$. reinhardtii was excellent both in controls and treatments. Volume-based growth rates were similar $(t=1.26 ; \mathrm{df}=4 ; p=0.277)$ and on average $\left( \pm 1\right.$ SD) $1.99(0.07) \mathrm{d}^{-1}$ and $1.91(0.08) \mathrm{d}^{-1}$ in controls and treatments, respectively. The Brachionus clearance rate was estimated $6.8 \pm 5.2 \mu 1$ rotifer $^{-1} \mathrm{~h}^{-1}$.

\section{Chemostat experiment}

In the two-stage system, $B$. calyciflorus was able to graze down $C$. reinhardtii to low biomass until complete extinction of the rotifers after 45 days (Fig. 4). In the one-stage system, however, $C$. reinhardtii was grazed down less (Fig. 4). B. calyciflorus was able to reach higher population densities in the two-stage system than in the one-stage system (Fig. 4). Over the entire period, $C$. reinhardtii biomass (expressed as biovolume) was significantly lower in the grazing vessel of the two-stage system ( $t$-test log transformed data : $t=3.77$, $d f=72, p<0.001)$ than in the one-stage system (Fig. 5). The mean number of rotifers $( \pm 1 \mathrm{SE})$ in the two-stage system $\left(56 \pm 9\right.$ animals $\left.\mathrm{ml}^{-1}\right)$ was significantly higher ( $t$-test $: t=2.26, d f=70, p=0.027$ ) than

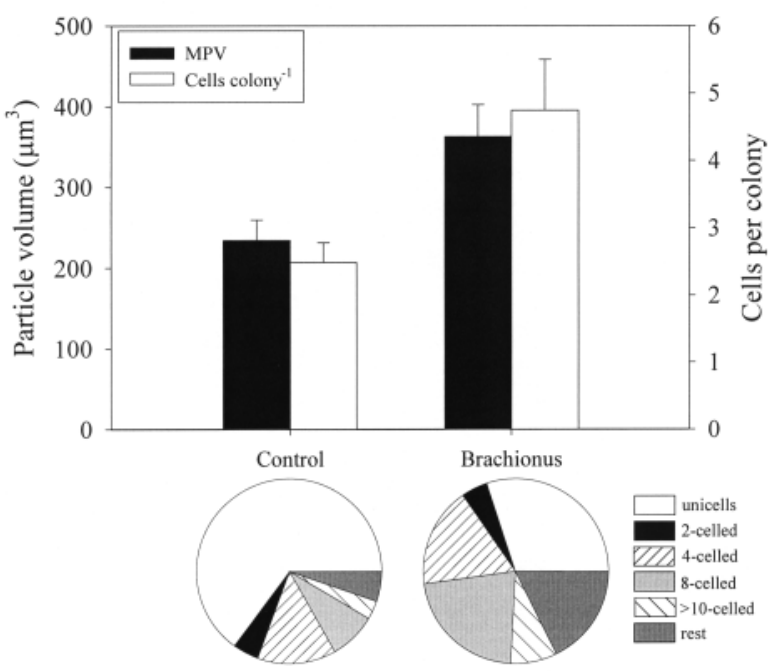

Fig. 2. Mean particle volume (MPV, $\mu \mathrm{m}^{3}$; filled bars) and mean number of cells per colony (open bars) of Chlamydomonas reinhardtii cultured for $25 \mathrm{~h}$ in the absence (Control) and presence of the rotifer Brachionus calyciflorus (Brachionus). Error bars indicate one standard deviation $(N=3)$. The pie diagrams reflect the composition, i.e. the share of unicells and differently sized colonies, of the Chlamydomonas populations.

in the one-stage system $\left(31 \pm 6\right.$ animals $\left.\mathrm{ml}^{-1}\right)$. Aggregate size of $C$. reinhardtii, expressed as mean particle volume $\left(\mathrm{MPV} \pm 1 \mathrm{SE}, \mu \mathrm{m}^{3}\right)$, was significantly lower ( $t$-test : $t=3.70, d f=72, p<0.001)$ in the two-stage system $\left(137.5 \pm 18.5 \mu \mathrm{m}^{3}\right)$ than in the one-stage sys-

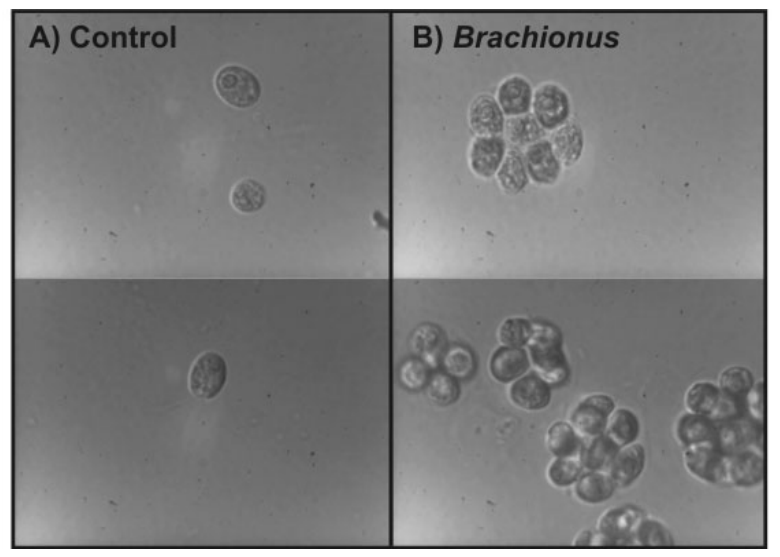

Fig. 3. Left panel A (Control) : Unicellular Chlamydomonas reinhardtii from populations grown for $25 \mathrm{~h}$ in the absence of rotifers. Right panel B (Brachionus) : Palmelloid Chlamydomonas observed in the presence of the rotifer Brachionus calyciflorus. 
tem $\left(227.1 \pm 15.5 \mu \mathrm{m}^{3}\right)$. In line with this result also the mean number of cells per $C$. reinhardtii aggregate was found to be significantly higher in the one-stage system than in the grazing vessel of the two-stage system $(t$-test : $\log$ transformed data $: t=-5.55 ; \mathrm{df}=29 ; p<$ 0.001) (Fig. 5). The compositions of the populations revealed that unicells made up $76 \pm 20 \%$ of the population in the two-stage grazing vessel, but only $46 \pm$ $14 \%$ in the one-stage system (Fig. 6). Moreover, aggregates with more than $10 \mathrm{C}$. reinhardtii cells were virtually absent in the two-stage system $(0.4 \pm 0.7 \%)$, but comprised $10 \pm 9 \%$ of the population in the one-stage system (Fig. 6).

\section{Discussion}

In the presence of the rotifer Brachionus calyciflorus, populations of the green alga Chlamydomonas reinhardtii expressed a higher share of palmelloids. These results support the findings of Mikheeva \& Kruchkova (1980) who first reported on the formation of palmelloid colonies in Chlamydomonas in the presence of herbivorous zooplankton, i.e. the cladoceran Moina rectirostris. Mikheeva \& Kruchkova (1980) re-

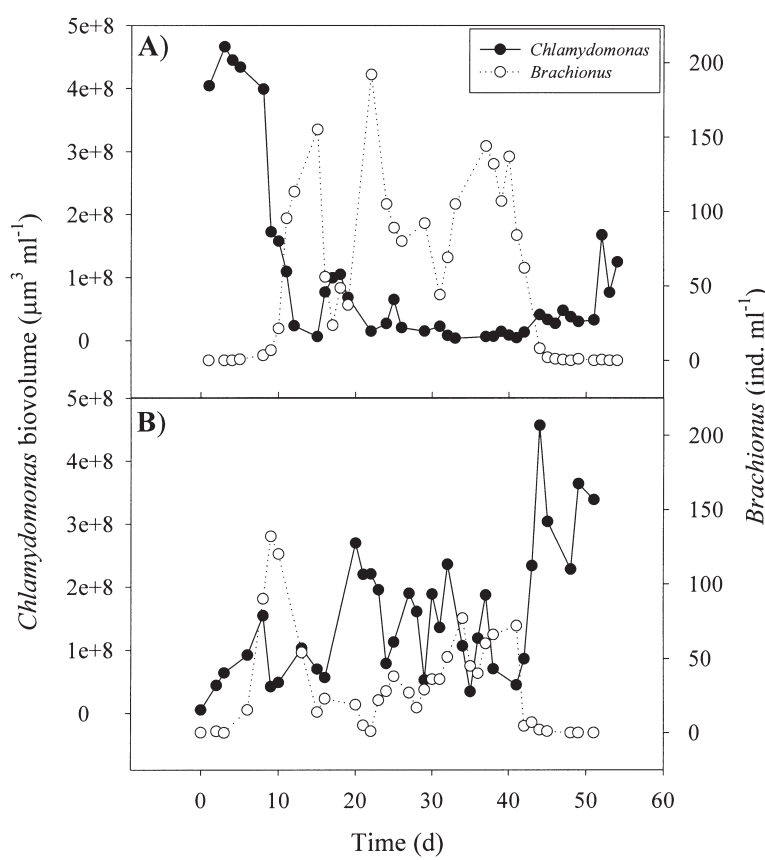

Fig. 4. Course of Chlamydomonas reinhardtii (filled symbols ; as biovolume in $\mu^{3} \mathrm{ml}^{-1}$ ) and Brachionus (open symbols, as individuals $\mathrm{ml}^{-1}$ ) in a two-reactor system (upper panel A) and a onereactor system (lower panel B). ported that palmelloid Chlamydomonas colonies ranged from 2 to 128 cells per colony. These authors have listed drawings of regularly arranged palmelloids, however, the present study yielded larger aggregates ( $>10$ cells per aggregate) that were irregularly shaped. In such colonies, $C$. reinhardtii cells loose their flagella and secrete mucous. Because a mucous envelope may give resistance to digestion (Porter 1975) and colonies resistance to ingestion (Hessen \& Van Donk 1993), palmelloid $C$. reinhardtii was hypothesised to be more protected against grazing than motile unicells.

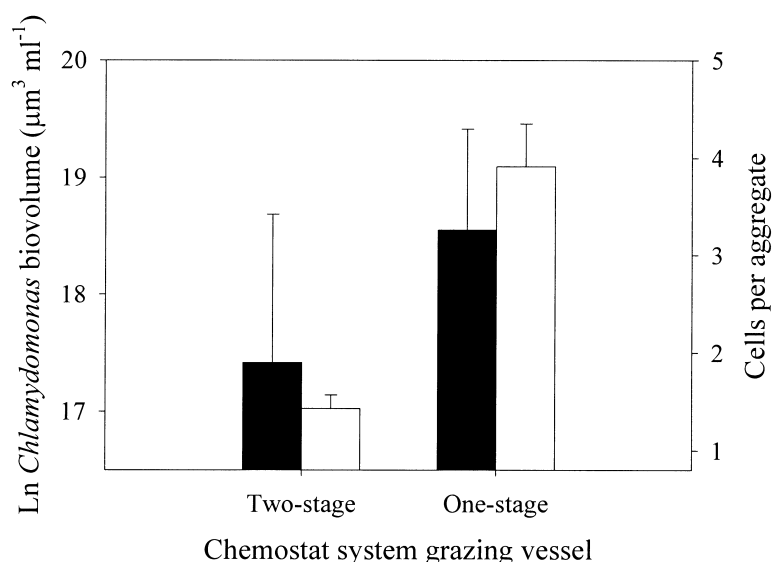

Fig. 5. Mean Chlamydomonas reinhardtii biovolume (filled bars ; natural log-transformed, \pm 1 SD) and mean number of cells per colony (open bars) in the grazing vessels of a two-stage Chlamydomonas- Brachionus system (Two-stage) and a one-stage system (One-stage).

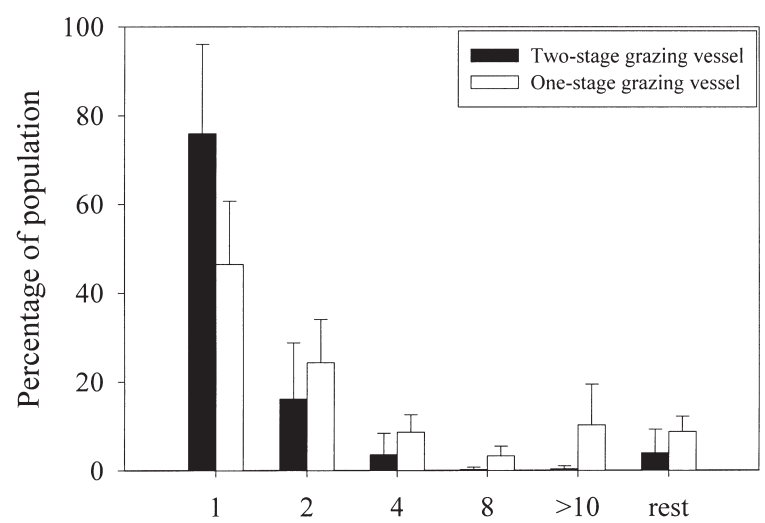

Fig. 6. Composition of Chlamydomonas reinhardtii populations in the grazing vessels of a two-stage Chlamydomonas- Brachionus system (filled bars) and a one-stage system (open bars) averaged over the entire experimental period of 51-54 days. 
In line with the expectations, in the one-stage grazeralga system, where rotifers and $C$. reinhardtii were cultured together, palmelloid colonies were formed. The morphological change coincided with lower rotifer abundance and higher algal biomass compared to a two-stage system in which unicellular $C$. reinhardtii was pumped into a rotifer culture placed in darkness. This is in concordance with the hypothesis that induced defences will reduce the energy flow from algae to grazers as was predicted in recent modelling studies (Vos et al. 2004).

In the two-stage system, $C$. reinhardtii did not form aggregates in the grazing-vessel, which means that light and thus growth is a prerequisite for the formation of colonies. This is identical to the formation of colonies in the green alga Chlorella, where active photosynthesis and continued interaction with the predator were found to be essential to maintain colonial Chlorella (Boraas et al. 1998). These Chlorella colonies were protected against grazing (Boraas et al. 1998), which the results of the present study showed to be the case for $C$. reinhardtii colonies. In that view, the formation of large colonies embedded in mucous could be adaptive as a defence to minimise the risk of being consumed. One of the prerequisites of such a grazerinduced response is that there should be a trade-off between the tax paid and the benefits of the response ; the advantage of an inducible defence is cost savings (Tollrian \& Harvell 1999). Also in Scenedesmus sp. active growth of the algae is a precondition for the formation of colonies (Lampert et al. 1994). The tax Scenedesmus sp. has to pay for forming protective colonies is an enhanced chance of sinking out of the trophogenic zone (Lürling \& Van Donk 2000). Undoubtedly the successful strategy of $C$. reinhardtii cells in maintaining a favourable position in the trophogenic zone through its mobility is undermined by forming colonies, in which $C$. reinhardtii cells loose their flagella and become embedded in mucous. It is expected that such palmelloids have much higher sinking rates than the flagellated unicells do have.

The absence of any palmelloid formation in darkness, despite the presence of grazers, not only means that active growth is required, but also that the colonies are not the result of existing cells budding together. Interestingly, in the grazing vessel in darkness the mean number of $C$. reinhardtii cells per aggregate was lower with on average 1.4 cells per colony than the 2.4 cells per colony in the algal growth vessel of the same system. A smaller colony size might indicate selective feeding by Brachionus and/or colony disintegration in the dark. The latter phenomenon is not unlikely becau- se Scenedesmus colonies disintegrate after a certain period in darkness, which will enhance the chance of being moved up to the trophogenic zone (Lürling 2003). Therefore, also C. reinhardtii palmelloids might shift from the colonial phenotypic variant to flagellated unicells after a period in the dark, but this needs thorough experimental validation.

Formation of colonies and concomitant mucous production probably caused lumping of existing cells and colonies into the larger multi-celled irregular-shaped C. reinhardtii aggregates that were detected in the onestage system. Because all systems were aerated we exclude the possibility of water movement as the sole causal factor for aggregate formation. Large aggregates were also observed when Scenedesmus was kept in the presence of live Daphnia, which seemed to be caused by clogging of live cells onto faecal pellets (Lürling 1999). Hessen \& Van Donk (1993) reported the occurrence of large multicelled aggregates with mean diameters of $50 \mu \mathrm{m}$ in the presence of live Daphnia too. They referred to it as a culture phenomenon, but there is no reason to assume that the formation of multicelled aggregates will be restricted to the laboratory. From the marine world, flocculation of algae, "marine snow", is a well-known phenomenon that may be caused by heterotrophic flagellates (Nygaard \& Hessen 1994) and that might inhibit copepod grazing (Malej \& Harris 1993). In freshwater systems, grazing by rotifers might also cause the development of large stable flocs consisting of algae and bacteria (Schlüter et al. 1987).

Several studies have demonstrated that the formation of protective colonies in freshwater green algae Actinastrum, Coelastrum, Desmodesmus, and Scenedesmus, and the marine prymnesiophyte Phaeocystis might be evoked by zooplankton associated chemicals (Hessen \& Van Donk 1993, Lürling 1998, Van Donk et al. 1999, Yasumoto et al. 2000, Tang 2003). Also B. calyciflorus was among the grazers that released chemicals, which stimulated the formation of colonies in Scenedesmus (Lürling \& Van Donk 1997). The role of zooplankton chemicals was, however, not tested explicitly in the current study. Nevertheless, the rapidity of the response of $C$. reinhardtii cells, as detected in the short-term assay, together with the low grazing rate (a clearance of only $8 \%$ of the volume in the experimental period) and high $C$. reinhardtii growth rate, indicates that selective grazing cannot fully account for the morphological changes. Alternatively, we cannot exclude aggregation of existing cells into colonies in the short-term assay. Further studies with zooplankton exudates, as well as the recently discovered Daphnia 
kairomones (Yasumoto et al. 2005), are needed to determine whether the morphological change in $C$. reinhardtii is evoked by chemical cues released from zooplankton.

Under nutrient-replete conditions in the absence of predators $C$. reinhardtii cells are usually single celled, biflagellated with a thin cell wall of which the twolayers are composed entirely of glycoproteins (Roberts et al. 1985). Resource limitation may cause C. reinhardtii to loose its flagella and the form a thicker inner cell wall layer (Van Donk et al. 1997). Thickening of the cell wall gave $C$. reinhardtii resistance to digestion and allowed cells to pass mostly intact and viable through the grazers gut (Van Donk et al. 1997). The results of the present study and those of Mikheeva \& Kruchkova (1980) suggest that under nutrient-replete conditions and in presence of predators, $C$. reinhardtii may form protective palmelloid colonies. Palmelloid formation could also be induced in $C$. reinhardtii when organic acids or EDTA caused chelation of calcium resulting in inhibited desegregation of daughter cells (Iwasa \& Murukami 1968, 1969). Anthropogenic compounds, such as the herbicide paraquat, might cause morphological changes in Chlamydomonas sp. This herbicide not only caused an increase in the cell volume of C. reinhardtii (Bray et al. 1993) ; it also induced the palmelloid colony formation in Chlamydomonas (Franqueira et al. 2000). Hence, several factors, natural and anthropogenic, may affect the morphology of Chlamydomonas species.

The cosmopolite appearance of Chlamydomonas species illustrates the wide range of environmental conditions those organisms can tolerate, which is reflected in the ease to isolate and grow many Chlamydomonas species in a broad range of culture media and conditions (Trainor \& Cain 1986). Chlamydomonas species can be found in freshwater bodies all around the world ranging from highly eutrophic, polluted to oligotrophic, acidic waters, in marine habitats, and they are encountered even in the soil (Hilton \& Trainor 1963, Sack et al. 1994) and in the atmosphere (Brown et al. 1964). The high flexibility of members of the genus Chlamydomonas is exemplified by Chlamydomonas species that were tremendously well-adapted to drying out of their habitat and were found to survive for 25 years in desiccated soil samples (Trainor 1985). The present study as well as the study of Mikheeva \& Kruchkova (1980) further illustrates the ability of Chlamydomonas species to track environmental changes and respond appropriately : when the risk of being consumed increases flagellates that are vulnerable to grazing may transform in grazing-resistant palmelloids.
Despite the fact that Chlamydomonas species are known for their ability to produce gelatinous and palmelloid stages (Van den Hoek et al. 1995), rather limited studies have been undertaken to investigate this phenomenon. Often such palmelloid stages are classified in the order Tetrasporales, because they are simply not recognised as Chlamydomonas (Van den Hoek et al. 1995). Clearly further research is needed to explore under which conditions $C$. reinhardtii shows the observed plasticity and to examine the underlying mechanisms. However, facing the mortal danger of an encounter with natural enemies implies a strong selection on the evolution of mechanisms to avoid predators or to avoid being eaten. Formation of colonies to different herbivores, i.e. Moina (Mikheeva \& Kruchkova 1980) and Brachionus (this study) could indicate a general response to grazing as has been observed for the green alga Scenedesmus obliquus that responded to a whole range of contrasting herbivores (Lürling 2003). In the case of Scenedesmus, the morphological response to the presence of grazers could be interpreted as an induced defence (Lürling 2003). We therefore suggest that at least one of the reasons why $C$. reinhardtii is capable of forming palmelloids is to cope with herbivory that is among the largest selective pressures on the phytoplankton.

\section{Acknowledgement}

This study was supported by a fellowship of the Royal Netherlands Academy of Arts and Sciences (KNAW).

\section{References}

Boraas M.E., Seale D.B. \& Boxhorn J.E. 1998. - Phagotrophy by a flagellate selects for colonial prey : a possible origin of multicellularity. Evol. Ecol., 12, 153-164.

Bray D.F., Bagu J.R. \& Nakamura K. 1993. - Ultrastructure of Chlamydomonas reinhardtii following exposure to paraquat: comparison of wild type and paraquat-resistant mutant. Can. J. Bot., 71, 174-182.

Brown R.M., Johnson C. \& Bold H. 1964. - Airborne algae : their abundance and heterogeneity. Science, 143, 583-585.

Franqueira D., Orosa M., Torres E., Herrero C. \& Cid A. 2000. - Potential use of flow cytometry in toxicity studies with microalgae. Sci. Tot. Environ., 247, 119-126.

Hessen D.O. \& Van Donk E. 1993. - Morphological changes in Scenedesmus induced by substances released from Daphnia. Arch. Hydrobiol., 127, 129-140.

Hilton R. \& Trainor F.R. 1963. - Algae from a Connecticut soil. Plant \& Soil, 19, 396-399.

Holm N.P., Ganf G.G. \& Shapiro J. 1983. - Feeding and assimilation rates of Daphnia pulex fed Aphanizomenon flos-aqua. Limnol. Oceanogr., 28, 677-687.

Hutchinson G.E. 1967. - A treatise of limnology. Vol. II. Introduction to lake biology and limnoplankton. New York, Wiley.

Iwasa K. \& Murakami S. 1968. - Palmelloid formation in Chlamydomonas. I. Palmelloid induction by organic acids. Physiol. Plant., 21, 1224-1231.

Iwasa K. \& Murakami S. 1969. - Palmelloid formation in Chlamy- 
domonas. I Mechanisms of palmelloid formation by organic acids. Physiol. Plant., 22, 43-50.

Lampert W., Rothhaupt K.O. \& von Elert E. 1994. - Chemical induction of colony formation in a green alga (Scenedesmus acutus) by grazers (Daphnia). Limnol. Oceanogr., 39, 1543-1550.

Lehman J.T. 1988. - Selective herbivory and its role in the evolution of phytoplankton growth strategies. Pages 369-387 in Growth and reproductive strategies of freshwater phytoplankton. Sandgren C.D. (ed.), Cambridge Univ. Press.

Lürling M. 1998. - Effect of grazing-associated infochemicals on growth and morphological development in Scenedesmus acutus Meyen (Chlorophyceae). J. Phycol., 34, 578-586.

Lürling M. 1999. - The smell of water. Grazer-induced colony formation in Scenedesmus. Wageningen University, ISBN 90-5808046-3, $270 \mathrm{pp}$.

Lürling M. 2003. - Phenotypic plasticity in the green algae Desmodesmus and Scenedesmus with special reference to the induction of defensive morphology. Ann. Limnol. - Int. J. Lim., 39, 85-101.

Lürling M. \& Van Donk E. 1996. - Zooplankton-induced unicell-colony transformation in Scenedesmus acutus and its effect on growth of herbivore Daphnia. Oecologia, 108, 432-437.

Lürling M. \& Van Donk E. 1997. - Morphological changes in Scenedesmus induced by infochemicals released in situ from zooplankton grazers. Limnol. Oceanogr., 42, 783-788.

Lürling M. \& Van Donk E. 2000. - Grazer-induced colony formation in Scenedesmus : Costs of being colonial ? Oikos, 88, 111-118.

Lynch M. 1980. - Aphanizomenon blooms : Alternate control and cultivation by Daphnia pulex. Pages 299-304 in Evolution and ecology of zooplankton communities. Kerfoot W.C. (ed.), University Press of New England, Hanover.

Malej A. \& Harris G.P. 1993. - Inhibition of copepod grazing by diatom exudates- a factor in the development of mucus aggregates. Mar. Ecol. Progr. Ser., 96, 33-42.

Mikheeva T.M. \& Kruchkova H.M. 1980. - Morphological changes in Chlamydomonas sp. and Scenedesmus acuminatus in the presence of zooplankton. Botanica, 5, 60-63. (In Russian).

Morales E.A., Trainor F.R. \& Schlichting C.D. 2002. - Evolutionary and ecological implications of plastic responses of algae. Constancea, 83, 23 pp. http://ucjeps.berkely.edu/constancea/83/morales_etal/plasticity.html

Nygaard K. \& Hessen D.O. 1994. - Diatom kills by flagellates. $\mathrm{Na}$ ture, 367,520

Peters R.H. 1984. - Methods for the study of feeding, grazing and assimilation by zooplankton. Pages 336-412 in A manual on methods for the assessment of secondary production in fresh waters. Downing J.A. \& Rigler F.H. (eds.). IBP Handbook 17, $2^{\text {nd }}$ edition, Blackwell, Oxford.

Porter K.G. 1973. - Selective grazing and differential digestion of algae by zooplankton. Nature, 244, 179-180.

Porter K.G. 1975. - Viable gut passage of gelatinous green algae ingested by Daphnia. Verh. int. Verein. Limnol., 19, 2840-2850.

Roberts K., Grief C., Hills G.J. \& Shaw P.J. 1985. - Cell wall glycoproteins : Structure and function. J. Cell Sci., 2, 105-127.

Sack L., Zeyl. C., Bell G., Sharbel T., Reboud X., Bernhardt T. \& Koelewyn H. 1994. - Isolation of four new strains of Chlamydomonas reinhardtii (Chlorophyta) from soil samples. J. Phycol.,
30, 770-773.

Schlüter M., Groeneweg J. \& Soeder C.J. 1987. - Impact of rotifer grazing on population dynamics of green microalgae in high-rate ponds. Wat. Res., 21, 1293-1297.

Sterner R.W. 1989. - The role of grazers in phytoplankton succession. Pages 107-170 in Plankton Ecology : succession in plankton communities. Sommer U. (ed.) Springer-Verlag Berlin, Heidelberg, New York

Tang K.W. 2003. - Grazing and colony size development in Phaeocystis globosa (Prymnesiopheceae) : the role of a chemical signal. J. Plankton Res., 25, 831-842.

Tollrian R. \& Harvell C.D. 1999. - The ecology and evolution of inducible defenses. Princeton University Press, New Jersey, 383 pp.

Trainor F.R. 1985. - Survival of algae in a desiccated soil : a 25 year study. Phycologia, 24, 79-82.

Trainor F.R. 1998. - Biological aspects of Scenedesmus (Chlorophyceae)-phenotypic plasticity. Nova Hedwigia, Beiheft 117, 367 pp.

Trainor F.R., Rowland H.L., Lylis J.C., Winter P.A. \& Bonanomi P.L. 1971. - Some examples of polymorphism in algae. Phycologia, 10, 113-119.

Trainor F.R. \& Cain J.R. 1986. - Famous algal genera. I. Chlamydomonas. Pages 81-127 in Progress in Phycological Research vol. 4.Round F.E. \& Chapman D.J. [eds.], Biopress Ltd., Bristol.

Van Donk E. 1997. - Defenses in phytoplankton against grazing induced by nutrient limitation, UV-B stress and infochemicals. Aquatic Ecology, 31, 53-58.

Van Donk E., Lürling M. \& Lampert W. 1999. - Consumer-induced changes in phytoplankton : inducibility, costs, benefits and impacts on grazers. Pages 89-10 in The ecology and evolution of inducible defenses. Tollrian R. \& Harvell, C.D. (eds.) Princeton University Press, New Jersey.

Van Donk E., Lürling M., Hessen D.O. \& Lokhorst G.M. 1997. - Altered cell wall morphology in nutrient-deficient phytoplankton and its impact on grazers. Limnol. Oceanogr., 42, 357-364.

Van den Hoek C., Mann D.G. \& Jahns H.M. 1995. - Algae : an introduction to phycology. Cambridge University Press, Cambridge, $623 \mathrm{pp}$.

van Holthoon F.L., van Beek T.A., Lürling M., Van Donk E. \& de Groot $Æ$. 2003. - Colony formation in Scenedesmus : a literature overview and further steps towards the chemical characterisation of the Daphnia kairomone. Hydrobiologia, 491, 241-254.

von Elert E. \& Franck A. 1999. - Colony formation in Scenedesmus : grazer-mediated release and chemical feature of the infochemical. J. Plankton Res., 21, 789-804.

Vos M., Kooi B.W., DeAngelis D.L. \& Mooij W.M. 2004. - Inducible defences and the paradox of enrichment. Oikos, 105, 471480 .

Yasumoto M., Ooi T., Kusumi T. \& Kasai F. 2000. - Characterization of Daphnia kairomone inducing morphological change of green alga Actinastrum sp. Tennen Yuki Kagobutsu Toronkai Keon Yoshishu, 42, 385-390. (In Japanese).

Yasumoto K., Nishigami A., Yasumoto M., Kasai F., Okada Y., Kusumi T., \& Ooi, T. 2005. - Aliphatic sulfates released from Daphnia induce morphological defense of phytoplankton : isolation and synthesis of kairomones. Tetrahedron Lett., 46, 4765-4767. 